\title{
Spatio-temporal Evaluation of the Quality of Effluents in Anionic Surfactants from the Soap and Cosmetics Units of the Industrial Area of Yopougon, Abidjan, Ivory Coast
}

\author{
Jean Missa Ehouman ${ }^{1, ~ *, ~ Y a f i g u i ~ T r a o r e ~}{ }^{1}$, Magloire Gnahoua Okou ${ }^{1}$, Juste-Geraud Boni ${ }^{3}$, \\ Ossey Bernard Yapo ${ }^{2,3}$, Nahosse Ziao ${ }^{1}$ \\ ${ }^{1}$ Thermodynamic Physico-Chemistry Laboratory of the Medium, Nangui Abrogoua University, Abidjan, Ivory Coast \\ ${ }^{2}$ Environmental Sciences Laboratory, Nangui Abrogoua University, Abidjan, Ivory Coast \\ ${ }^{3}$ Central Environment Laboratory, Ivorian Anti-pollution Center, Abidjan, Ivory Coast
}

Email address:

jeanmissa@gmail.com (J. M. Ehouman)

*Corresponding author

\section{To cite this article:}

Jean Missa Ehouman, Yafigui Traore, Magloire Gnahoua Okou, Juste-Geraud Boni, Ossey Bernard Yapo, Nahosse Ziao. Spatio-temporal Evaluation of the Quality of Effluents in Anionic Surfactants from the Soap and Cosmetics Units of the Industrial Area of Yopougon, Abidjan, Ivory Coast. International Journal of Environmental Monitoring and Analysis. Vol. 9, No. 5, 2021, pp. 129-135.

doi: 10.11648/j.ijema.20210905.14

Received: September 8, 2021; Accepted: September 24, 2021; Published: September 29, 2021

\begin{abstract}
The anionic surfactants used in the soap industry and cosmetics appear as indicators of pollution of aquatic biodiversity. Moreover, these industries have experienced rapid growth in Côte d'Ivoire in recent years. Most of them are located in the Yopougon industrial area, thus continuously discharging their effluents into the Ebrié lagoon. This situation could lead to environmental, health and socio-economic disaster. Consequently, the evaluation of the quality of these effluents in anionic surfactants constitutes the starting point for the effect of identifying suitable ways for an efficient management of their use and their future. Four effluent sampling campaigns of ten units from this area were carried out over a period of one year. Anionic surfactants were analyzed by the methylene blue method. The analysis of the concentrations determined and the spatio-temporal analysis of the quality of the effluents according to the analysis of variance with repeated measures were carried out. It appears that all the effluents are very loaded with anionic surfactants and are grouped into two classes. Units Y2, Y6 and Y9 have an average concentration of anionic surfactants varying between 203,740 $\pm 157,544(\mathrm{mg} / \mathrm{L}$. EASL) and $275,323 \pm 255,811(\mathrm{mg} / \mathrm{L}$. EASL). The group (Y1, Y3, Y4, Y5, Y7, Y8 and Y10) records an average concentration in this parameter oscillating between $8.305 \pm 6,508(\mathrm{mg} / \mathrm{L}$. EASL) and 71.750 $\pm 91,485(\mathrm{mg} / \mathrm{L}$. EASL).
\end{abstract}

Keywords: Effluents, Cosmetic Soap Factories, Anionic Surfactants, Spatio-temporal Variation, Analysis of Variance, Repeated Measures

\section{Introduction}

The soap and cosmetics sector has experienced a considerable boom in detergent and cosmetic products thanks to the growing needs of the rapidly growing population. These industrial units are mainly concentrated in the industrial zone of Yopougon [1]. They contribute to the production of a high proportion of effluents in the Abidjan area generated by the use of water in the process [2]. These effluents loaded with various pollutants are discharged into the Ebrié lagoon like the other industrial units without treatment due to a lack of sanitation facilities $[3,4]$. Anionic surfactants are one of the most suspected pollutants in soap and cosmetic effluents because they constitute the essential active ingredient in formulation thanks to their functional diversity (detergency, emulsion, solubilization, etc.) $[5,6]$. The studies carried out have shown the occurrence of these organic micropollutants in various environmental compartments (surface water, wastewater, sediments, rivers, etc.) [7]. Indeed, the fate of 
untreated anionic surfactants released into the natural environment (sea, lagoon) represents a risk for aquatic organisms. Particularly fish and algae, which suffer from the toxicity of anionic surfactants $[8,9]$. Since then, anionic surfactants appear to be good indicators of pollution of aquatic biodiversity [10]. Faced with these indicators environmental, health and socioeconomic disaster, the evaluation of the quality of anionic surfactant effluents from soap and cosmetic units in the industrial area is proving to be essential. This approach constitutes the starting point for the exploration of a field of research in order to identify suitable ways for an efficient use and a good management of their future. This specifically involves determining the concentrations of this micropollutant and evaluating the level of pollution over time. In addition, an analysis of the spatial variation of the units is necessary in order to target the soap and cosmetics industries for good management of their effluent.

\section{Material and Method}

\subsection{Study Area and Location of the Soap and Cosmetic Industries}

The Yopougon industrial zone is located north of the Banco plateau. Its surface area is $9.73 \mathrm{~km}^{2}$ and today has around 155 industrial establishments [11]. Two main channels ensure the evacuation of its wastewater. This is the UNIWAX collector and the industrial zone collector. These two canals meet a little further before reaching the lagoon at the level of the village Azito [12]. The effluents from the Yopougon industrial zone, in particular those from the soap and cosmetic industries, are discharged into the Ebrié lagoon. The ten (10) Soap and Cosmetic Industries targeted according to the intensity of their activities, are coded from Y1 to Y10. The effluents of these soap industries were studied during our thesis work [13]. The geographic coordinates of these study sites are listed in the following table (Table 1).

Table 1. Geographical coordinates in UTM of sampling stations.

\begin{tabular}{lllll}
\hline \multirow{2}{*}{ Stations } & UTM coordinates & & UTM coordinates \\
\cline { 2 - 3 } & Longitude & Latitude & Stations & Longitude \\
\hline Y1 & 379823.4907 & 593298.2033 & Y6 & 379390.5019 \\
Y2 & 379633.8378 & 593953.3849 & Y7 & 379669.9425 \\
Y3 & 379691.3724 & 593342.5507 & Y8 & 379655.8395 \\
Y4 & 379690.4183 & 593554.3849 & Y9 & 379671.4536 \\
Y5 & 379602.4949 & 593400.7522 & Y10 & 379379.8019 \\
\hline
\end{tabular}

The mapping of the study area thus carried out (Figure 1) shows the various targeted soap industries, their location as well as the lagoon network and the evacuation channels for their effluents.

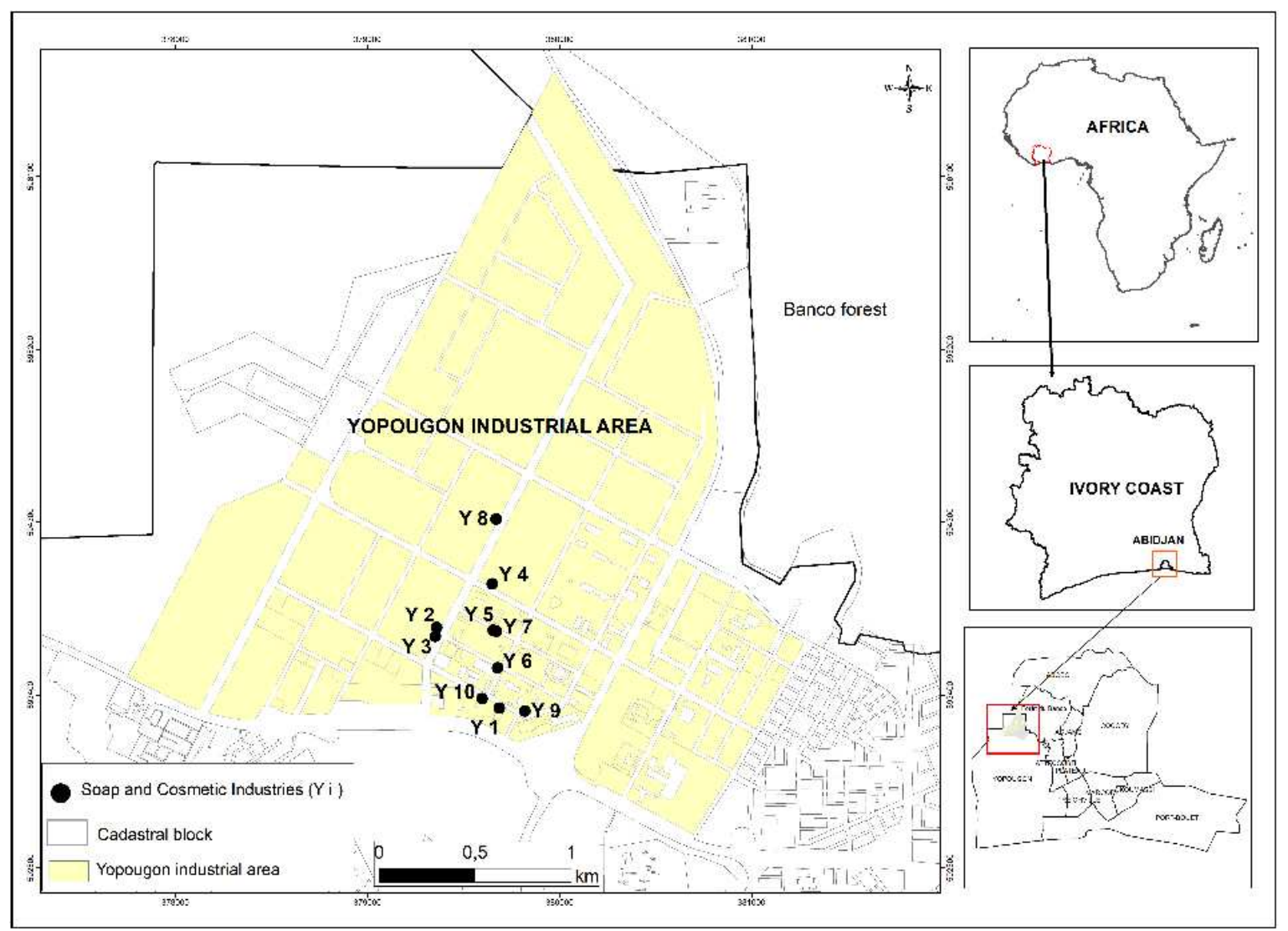

Figure 1. Yopougon industrial area and soap and cosmetic industries: soap factories (Y1-Y10). 


\subsection{Study Material, Sampling and Analysis}

Preliminary investigations in this industrial zone made it possible to target ten (10) soap and cosmetic units which discharge their effluents directly into the Ebrié lagoon. The study material therefore consists of samples of different effluents taken from these ten (10) units. The sampling equipment consists of a GPS (Global Positioning System) GPS map 60CSx GARMIN brand for the determination of the geographical coordinates of the sampling sites, of a landing net which was used to take samples of industrial liquid discharges from soap factories and of a BUHLER 2000 portable autosampler of the HACH LANGE brand. Anionic surfactants (AS) were measured by molecular absorption using a $\mathrm{HACH} / \mathrm{DR} 6000$ spectrometer.

\subsection{Reagents and Products}

The reagents and the products used in the context of this study are of analytical quality. The anionic surfactant used as a standard for the assay of anionic surfactants is dodecylbenzene sulfonate, Sigma-ALDRICH brand product and reference 24328995754.

\subsection{Sampling}

Under the direction of CIAPOL through its Central Environmental Laboratory (LCE), four (04) sampling campaigns were carried out from May 2016 to April 2017. The process water and the production system washing water are stored in tanks during production. TOAt the end of production, sampling is carried out before discharging these effluents into the receiving environment. The effluent flow time is estimated at less than 1 hour 30 minutes. For each site, continuous sampling for 1 hour is carried out using a BUHLER 2000 portable automatic sampler from $\mathrm{HACH}$ LANGE, fitted with an isothermal enclosure. It is programmed to carry out integrative samples over 1 hour, by taking $250 \mathrm{~mL}$ of effluents every 15 minutes. Four series of samples are taken in 1 hour to constitute a composite sample of one hour. The composite sample per site thus formed is taken using a dip net. These samples are placed in glass bottles with a capacity of $1 \mathrm{~L}$, previously washed with distilled water [14]. Ten composite samples per campaign are retained for analysis, ie a total of 40 samples. The average samples taken and labeled are protected from light in coolers containing carboglaces at temperatures of $4^{\circ} \mathrm{C}$. Upon arrival at the laboratory, these samples are stored in a freezer and analyzed within 24 hours [14].

\subsection{Analysis Methods for Anionic Surfactants and Data Processing}

\subsubsection{Analysis of Anionic Surfactants}

Anionic Surfactants (AS) are analyzed by forming a colored anionic surfactant/methylene blue complex (MBAS). The measurement is carried out at $650 \mathrm{~nm}$ by molecular absorption spectrophotometry. This method of global analysis of anionic surfactants by methylene blue (Methylene Blue Active Substances-MBAS) (NF T 90-039: 1994) used for this purpose, has given satisfactory results in several analyzes of anionic surfactants. In different environments (wastewater, effluents, river water, sediment, etc.) $[15,16]$. The concentration of anionic surfactants contained in the sample is determined relative to a calibration curve produced according to RODIER. The standard used in the context of this analysis is dodecylbenzene sulfonate (DBS), product Sigma-ALDRICH (reference 243289957 54). It is an anionic surfactant of the linear alkylbenzene sulfonate (ASL) family widely used as a standard in several analyzes of anionic surfactant [17]. The calibration curve established for the analysis of anionic surfactants is given in Figure 2 below. For an absorbance obtained and plotted on the curve, the concentration of anionic surfactants expressed in $\mathrm{mg} / \mathrm{L}$ by equivalence of linear alkylbenzene sulfonates (E ASL) is determined.

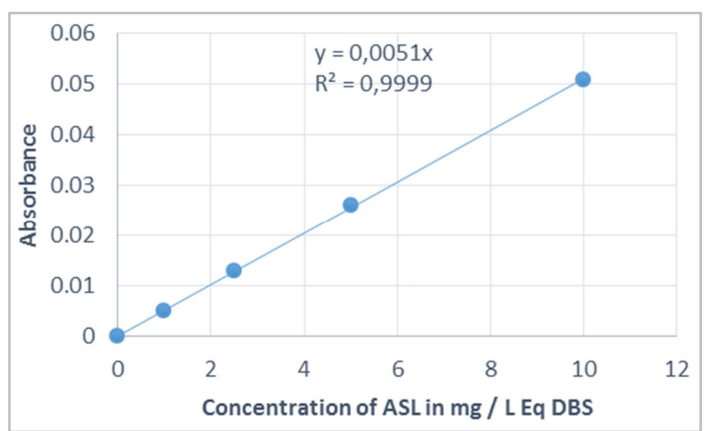

Figure 2. Calibration curve for reading the concentrations of anionic surfactants in the effluents analyzed.

\subsubsection{Statistical Data Processing}

The data obtained following the various campaigns and laboratory analyzes were subjected to statistical processing. These statistical treatments were carried out using the XLSTAT 2016 software according to repeated measures ANOVA. The comparison of the anionic surfactant concentrations measured between the different effluents from the different stations was carried out using the Kruskal-Wallis non-parametric test. Dunn's average rank multiple comparison test followed to indicate significant differences between the soap and cosmetic industries. The significance level for these tests was set at $\mathrm{p}<0.05$.

\section{Results}

\subsection{Temporal Variation in the Quality of Effluents from the Soap and Cosmetic Industries by Anionic Surfactant}

The temporal variation in the quality of effluents from the soap and cosmetic industries using anionic surfactant is illustrated by the Figures 3A, 3B, 3C and 3D. The indices (a, $\mathrm{b}, \mathrm{c}$ and d) represent the four sampling campaigns carried out per quarter over the period from May 2016 to April 2017. Of the forty measurements carried out, thirty-one (31) 
times the surfactant concentration anionic values of effluents remained above the French regulatory value (10 $\mathrm{mg} / \mathrm{L}$ ) [18]. About $78 \%$ of the effluents analyzed are highly loaded with anionic surfactants over all four six-monthly campaigns. However, the temporal variation of the concentration of anionic surfactant shows that at least all the units have a concentration of this micropollutantgreater than $10 \mathrm{mg} / \mathrm{L}$ over the four campaigns carried out.

\subsection{Average Concentrations of Anionic Surfactants in the Effluents of the Soap Factories and Cosmetics Units of Yopougon}

The average concentrations of anionic surfactants in the effluents characterized over all of the four campaigns are given in Table 2 .

Table 2. Average concentrations of anionic surfactants ( $\mathrm{mg} / \mathrm{L} . \mathrm{EASL})$ analyzed over all four campaigns.

\begin{tabular}{lllll}
\hline Stations & Observations (n) & Minimum & Maximum & Mean \\
\hline Y1 & 12 & 2.740 & 47.100 & 23.875 \\
Y2 & 12 & 77.760 & 552.430 & 253.070 \\
Y3 & 12 & 12.310 & 75.300 & 46.955 \\
Y4 & 22.160 & 50.400 & 31.682 \\
Y5 & 12 & 6.200 & 21.250 & 15.092 \\
Y6 & 12 & 0.150 & 450.100 & 203.740 \\
Y7 & 12 & 0.1500 & 17.7200 & 8.305 \\
Y8 & 12 & 63.720 & 98.720 & 33.305 \\
Y9 & 12 & 4.750 & 675.100 & 23.569 \\
Y10 & 12 & 219.080 & 5.372 \\
\hline
\end{tabular}

This table reveals that nine (9) out of ten (10) units have average anionic surfactant concentrations greater than $10 \mathrm{mg} / \mathrm{L}$. Only unit Y7 has an average concentration lower than this reference value $(10 \mathrm{mg} / \mathrm{L})$.

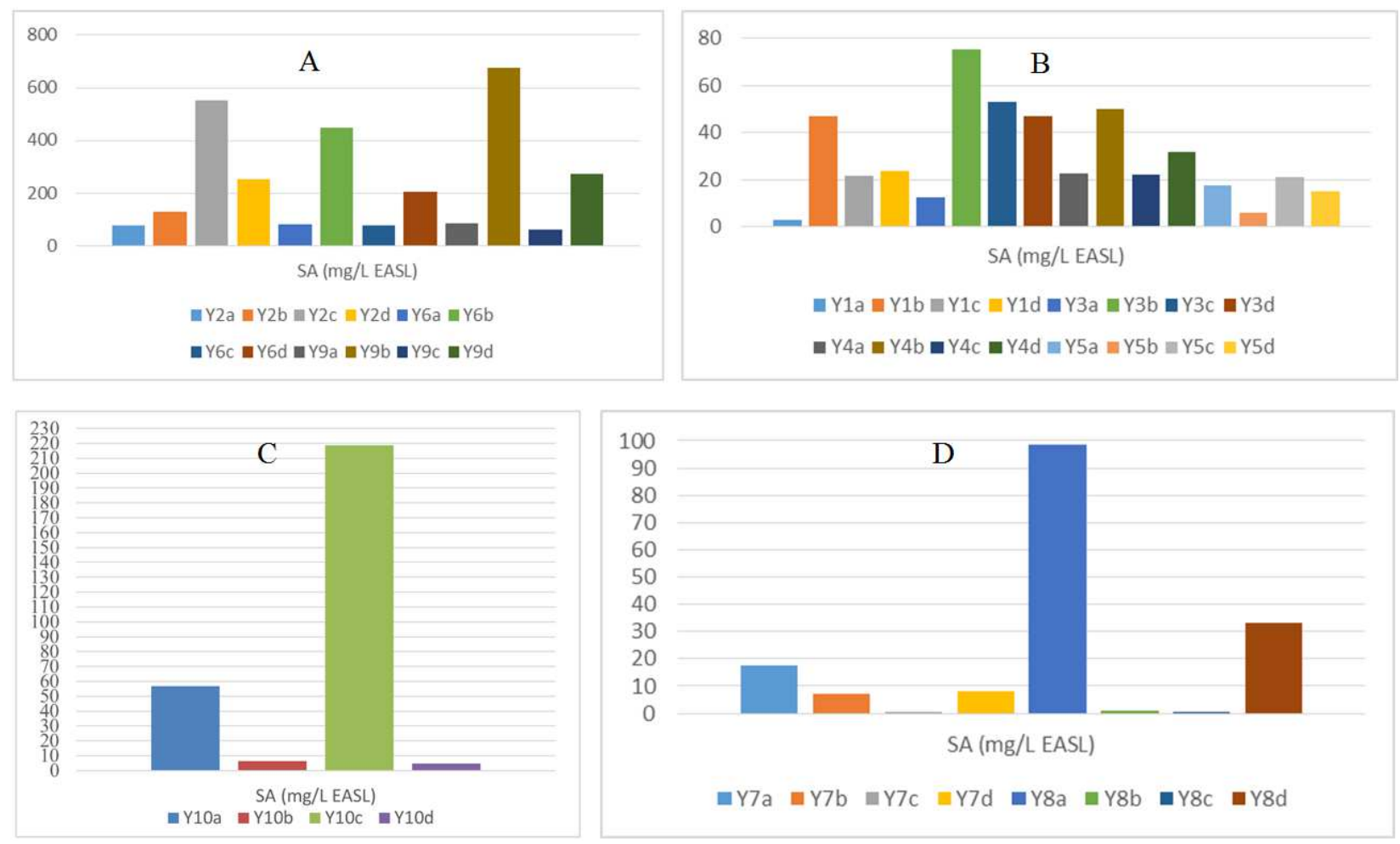

Figure 3. Temporal variation in the quality of effluents from the soap and cosmetic industries using anionic.

\subsection{Inter-soap and Cosmetic Variation in the Quality of Effluents by Anionic Surfactant}

The variation between soap factories and cosmetics is carried out according to repeated measures ANOVA from the raw data relating to the four sampling campaigns. The test of significant difference between industrial units and the classification of these soap and cosmetic units will be the subject of this statistical study.

\subsubsection{Inter-soap and Cosmetic Significance Tests}

The analysis of Table 3 shows a significant difference between the soap and cosmetic unit $Y 9$ and the group of soap factories (Y1, Y3, Y4, Y5, Y7, Y8 and Y10) with a p-value $<0.0001$. This same group (Y1, Y3, Y4, Y5, Y7, Y8 and Y10) establishes a significant difference with Y2 on the one hand and with Y 6 on the other hand at $\mathrm{p}$-value $<0.0001$. On the other 
hand, there is no significant difference between units Y2, Y6 and Y9 with p-value $>0.0001$. Also, the significant difference between soap factories and cosmetics is not observed between the units of the group (Y1, Y3, Y4, Y5, Y7, Y8 and Y10).

Table 3. Repetition/Fisher (LSD)/Analysis of differences between modalities with a 95\% confidence interval.

\begin{tabular}{|c|c|c|c|c|c|c|c|c|c|}
\hline $\begin{array}{l}\mathrm{Yi} / \mathrm{Yj} \\
\text { comparison }\end{array}$ & $\begin{array}{l}\text { Standardized } \\
\text { difference }\end{array}$ & $\begin{array}{l}\text { Critical } \\
\text { value }\end{array}$ & Pr $>$ Diff & Significant & $\begin{array}{l}\mathbf{Y i} / \mathbf{Y j} \\
\text { comparison }\end{array}$ & $\begin{array}{l}\text { Standardized } \\
\text { difference }\end{array}$ & $\begin{array}{l}\text { Critical } \\
\text { value }\end{array}$ & $\begin{array}{l}\text { Pr> } \\
\text { Diff }\end{array}$ & Significant \\
\hline Y9/Y7 & 5.5591 & 1.9818 & $<0.0001$ & Yes & $\mathrm{Y} 6 / \mathrm{Y} 10$ & 2.7479 & 1.9818 & 0.0070 & Yes \\
\hline Y9/Y5 & 5.4178 & 1.9818 & $<0.0001$ & Yes & $\mathrm{Y} 10 / \mathrm{Y} 7$ & 1.3209 & 1.9818 & 0.1893 & No \\
\hline Y9/Y1 & 5.2349 & 1.9818 & $<0.0001$ & Yes & Y10/Y5 & 1.1796 & 1.9818 & 0.2407 & No \\
\hline Y9/Y4 & 5.0724 & 1.9818 & $<0.0001$ & Yes & Y10/Y1 & 0.9967 & 1.9818 & 0.3211 & No \\
\hline Y9/Y8 & 5.0386 & 1.9818 & $<0.0001$ & Yes & $\mathrm{Y} 10 / \mathrm{Y} 4$ & 0.8342 & 1.9818 & 0.4060 & No \\
\hline Y9/Y3 & 4.7544 & 1.9818 & $<0.0001$ & Yes & $\mathrm{Y} 10 / \mathrm{Y} 8$ & 0.8004 & 1.9818 & 0.4252 & No \\
\hline Y9/Y6 & 1.4903 & 1.9818 & 0.1390 & No & $\mathrm{Y} 3 / \mathrm{Y} 7$ & 0.8047 & 1.9818 & 0.4228 & No \\
\hline Y9/Y2 & 0.4633 & 1.9818 & 0.6441 & No & Y3/Y5 & 0.6634 & 1.9818 & 0.5085 & No \\
\hline $\mathrm{Y} 2 / \mathrm{Y} 7$ & 5.0958 & 1.9818 & $<0.0001$ & Yes & $\mathrm{Y} 3 / \mathrm{Y} 1$ & 0.4805 & 1.9818 & 0.6318 & No \\
\hline Y2/Y5 & 4.9545 & 1.9818 & $<0.0001$ & Yes & $\mathrm{Y} 3 / \mathrm{Y} 4$ & 0.3180 & 1.9818 & 0.7511 & No \\
\hline $\mathrm{Y} 2 / \mathrm{Y} 1$ & 4.7717 & 1.9818 & $<0.0001$ & Yes & $\mathrm{Y} 3 / \mathrm{Y} 8$ & 0.2842 & 1.9818 & 0.7768 & No \\
\hline $\mathrm{Y} 2 / \mathrm{Y} 4$ & 4.6091 & 1.9818 & $<0.0001$ & Yes & Y8/Y7 & 0.5205 & 1.9818 & 0.6038 & No \\
\hline $\mathrm{Y} 2 / \mathrm{Y} 8$ & 4.5753 & 1.9818 & $<0.0001$ & Yes & Y8/Y5 & 0.3792 & 1.9818 & 0.7053 & No \\
\hline $\mathrm{Y} 2 / \mathrm{Y} 3$ & 4.2911 & 1.9818 & $<0.0001$ & Yes & Y8/Y1 & 0.1963 & 1.9818 & 0.8447 & No \\
\hline Y2/Y6 & 1.0270 & 1.9818 & 0.3067 & No & Y4/Y7 & 0.4867 & 1.9818 & 0.6274 & No \\
\hline Y6/Y7 & 4.0688 & 1.9818 & $<0.0001$ & Yes & Y4/Y5 & 0.3454 & 1.9818 & 0.7305 & No \\
\hline Y6/Y5 & 3.9275 & 1.9818 & 0.0002 & Yes & $\mathrm{Y} 4 / \mathrm{Y} 1$ & 0.1625 & 1.9818 & 0.8712 & No \\
\hline Y6/Y1 & 3.7446 & 1.9818 & 0.0003 & Yes & $\mathrm{Y} 1 / \mathrm{Y} 7$ & 0.3242 & 1.9818 & 0.7464 & No \\
\hline Y6/Y4 & 3.5821 & 1.9818 & 0.0005 & Yes & Y1/Y5 & 0.1828 & 1.9818 & 0.8553 & No \\
\hline Y6/Y8 & 3.5483 & 1.9818 & 0.0006 & Yes & Y5/Y7 & 0.1413 & 1.9818 & 0.8879 & No \\
\hline Y6/Y3 & 3.2641 & 1.9818 & 0.0015 & Yes & & & & & \\
\hline LSD-value & & & & & & & 95.1893 & & \\
\hline
\end{tabular}

\subsubsection{Classification Between Soap Factories and Cosmetics}

Table 4 reveals two classes of soap and cosmetic units. Group A consists of units (Y2, Y6 and Y9), with an average concentration of anionic surfactant which is between 203.740 $\mathrm{mg} / \mathrm{L}$ and $275.323 \mathrm{mg} / \mathrm{L}$. As for group B, it is composed of units (Y1, Y3, Y4, Y5, Y7, Y8 and Y10) with an average concentration of anionic surfactant ranging between 8.305 $\mathrm{mg} / \mathrm{L}$ and $71.750 \mathrm{mg} / \mathrm{L}$.

Table 4. Classification of soap and cosmetic industries according to the quality of effluents in anionic surfactants.

\begin{tabular}{llll}
\hline Modality & Estimated averages & Groups & \\
\hline Repeat- Y9 & 275.323 & A & \\
Repeat- Y2 & 253.070 & A & \\
Repeat- Y6 & 203.740 & A & \\
Repeat- Y10 & 71.750 & & B \\
Repeat- Y3 & 46.955 & & B \\
Repeat- Y8 & 33.305 & B \\
Repeat- Y4 & 31.682 & B \\
Repeat- Y1 & 23.875 & & B \\
Repeat- Y5 & 15.092 & B \\
Repeat- Y7 & 8.305 & B \\
\hline
\end{tabular}

\section{Discussion}

Around $78 \%$ of the effluents analyzed are highly loaded with anionic surfactants over all four quarterly campaigns carried out. In addition, all the effluents analyzed have at least a concentration of this micropollutant greater than $10 \mathrm{mg} / \mathrm{L}$ over the four sampling campaigns.

Furthermore, over this same period, $90 \%$ of the soap and cosmetic units in the Yopougon industrial zonepresent effluents with an average anionic surfactant concentration greater than $10 \mathrm{mg} / \mathrm{L}$. Consequently, all the effluents analyzed over the entire sampling period remain indicators of pollution by anionic surfactant in this industrial area. Moreover, the study of the inter-unit variation of soap factories and cosmetics, grouped the ten units into two classes. The group of units (Y2, Y6 and Y9) whose anionic surfactant quality of the effluents is significantly different from that of the group (Y1, Y3, Y4, Y5, Y7, Y8 and Y10), records worrying levels of this organic pollutant. ranging from 10 to 27 times the French reference standard. The second group (Y1, Y3, Y4, Y5, Y7, Y8 and Y10) is no exception to this ecological disaster because the concentration of anionic surfactant in their effluents greatly exceeds this reference value $(10 \mathrm{mg} / \mathrm{L})$. In view of the above, it can be said that the soap and cosmetic units studied continuously pollute the Ebrié lagoon with anionic surfactants. Moreover, in the absence of a guide value in the Ivorian legislation, it is difficult to situate ourselves on this very toxic micropollutant. However, even in trace amounts, these micropollutants discharged into the lagoon without treatment, causing pollution of the aquatic ecosystem [17, 19]. In fact, the high concentrations of soap factory effluents of untreated anionic surfactants discharged into the marine and lagoon waters of the Abidjan area represent a risk for aquatic organisms [20, 21]. Specifically for fish, the gill tissues exposed to the non-degraded molecules present a danger for a content exceeding the toxic threshold, that is to say with an EC50 varying from 0.7 to $18 \mathrm{mg}^{-1} \mathrm{~L}^{-1}$ [22]. Also, 
Algae, a food source for fish, suffer from the toxicity of anionic surfactants [23], thus impacting the proper development of fishery resources. Consequently, the continuous impoverishment of the Ebrié lagoon and of the marine waters of their fishery resources, can cause socioeconomic, food and health consequences for certain lagoon peoples. Moreover, the accumulation of these micropollutants in sediments and in aquatic biodiversity is still real, especially since these effluents are also very loaded with suspension according to our work on the same soap and cosmetic units [24]. High concentrations of suspended solids (SS) generated by the waste from soap factories, coupled with the high load of anionic surfactants (AS), can constitute proven signs of pollution of the Ebrié lagoon [25]. In fact, suspended solids transport various chemical elements by adsorption into the aquatic environment, including anionic surfactants, in particular linear alkylbenzenesulphonates [26]. Specifically, particulate $\mathrm{C} 12$ and $\mathrm{C} 13$ homologs preferentially associate with suspended matter [26].

\section{Conclusion}

This work, drawn from our thesis work, made it possible to assess the quality of effluents from ten (10) soap and cosmetic units with anionic surfactant from the Yopougon industrial zone. It emerges from this study that the effluents of all the targeted soap and cosmetic units are very loaded with anionic surfactant. These effluents are therefore certain indicators of pollution. In addition, the analysis of the variation between soap factories and cosmetics grouped these soap factories into two classes according to the quality of this micropollutant of their effluents. The soap and cosmetic units Y2, Y6 and Y9 appear to be the "most polluting" units in anionic surfactant. The State of Ivory Coast through CIAPOL and ANDE must take a look for an effective management of their liquid discharge. Also, the decision-makers must take appropriate decisions, going in the direction of the use and the future of this micropollutant in terms of protection of the Ebrié lagoon. For our part, the effluents of theY2, Y6 and Y9 will be the subject of other studies in order to propose a bioprocess for the treatment of their effluent for reuse within the framework of the circular economy.

\section{Acknowledgements}

The authors sincerely thank the Sub-Directorate of Services for the Inspection of Classified Installations (SD/SIIC) and the Central Environmental Laboratory of the Ivorian Anti-pollution Center (LCE-CIAPOL) for their invaluable technical support for the success of this project. research work.

\section{References}

[1] Kablan N. Hassy J. et al (2013). Impact environnemental de la zone industrialo-portuaire (ZIP) d'Abidjan. Pp 18 57-78 81.
[2] PARE/PME (2014). Projet d'Appui à la revitalisation et à la gouvernance des PME. Etude économique sur les zones industrielles. Pp 436.

[3] DONGO K. R, NIAMKE B. F, ADJE A. F., BRITTON G. H., Laurent NAMA A. L., ANOH K. P, ADIMA A. A et ATTA K. (2013). Impacts des effluents liquides sur l'environnement urbain d'Abidjan-Côte d'Ivoire. Int. J. Biol. Chem. Sci. 7 (1): 404-420.

[4] KOUAME K. V. (2012). Caractérisation physicochimique et impacts éco toxicologiques des effluents industriels dans la lagune Ebrié. Thèse de doctorat à l'Université Nangui Abrogoua, Abidjan, Côte d'Ivoire. Pp 197.

[5] Ho Tan Taî, et al (2008). Formulation des Détergents, Pp 12-36.

[6] Ravalason H. et Laczka O. (2003). Bilan et critique de la législation européenne sur les détergents: Application aux tensioactifs anioniques et plus Particulièrement aux alkylbenzènes sulfonates linéaires (LAS). In: Projet de branche, $32 \mathrm{Pp}$.

[7] Cantarero, S., Camino-Sanchez, F. J., Zafra-Gomez, A., Ballesteros, O., Navalon, A., Vilchez, J. L., Verge, C., Reis, M. S. and Paraiva, P. M. (2012). Evaluation of the Presence of Major Anionic Surfactants in Marine Sediments. Marine Pollution Bulletin, 64, 587-594. https://doi.org/10.1016/j.marpolbul.2011.12.015

[8] Hampel, M., Mauffret, A., Pazdro, K. and Blasco, J. (2012) Anionic Surfactant Linear Alkylbenzene Sulfonates (LAS) in Sediments from the Gulf of Gdańsk (Southern Baltic Sea, Poland) and Its Environmental Implications. Environmental Monitoring and Assessment, 184, 6013-6023. https://doi.org/10.1007/s10661-011-2399-6.

[9] M. Lechuga, M. Fernández-Serrano n, E. Jurado, J. Núñez-Olea, F. Ríos (2016). Acute toxicity of anionic and non-ionic surfactants to aquatic organisms. Ecotoxicology and Environmental Safety125 (2016) 1-8.

[10] Könnecker G, Regelmann J, Belanger S et al (2011). Environmental properties and aquatic hazard assessment of anionic surfactants: physico-chemical, environmental fate and ecotoxicity properties. Ecotoxicol Environ Saf 74: 1445-1460. https://doi.org/10.1016/J.ECOENV.2011.04.015

[11] GNAGNE A., J., E., Y, YAPO B., O., MEITE L. KOUAME. K. V ANDRE A. GADJI A., MAMBO V., HOUENOU P (2015). Caractérisation physico-chimique et bactériologique des eaux usées brutes du réseau d'égout de la ville d'Abidjan. Int. J. Biol. Chem. Sci. 9 (2): 1082-1093.

[12] GNAGNE A., J., E., Y (2016). Caractérisation des effluents drainés par le réseau d'eaux usées de la ville d'Abidjan et prédiction des MES et de la DCO à partir de la mesure de la turbidité. Thèse de doctorat, Université Nangui Abrogoua, Abidjan, Côte d'Ivoire. Pp 213.

[13] EHOUMAN J. M., YAPO O. B, GNAGNE. A. E. I. E. Y, ZIAO N. (2017). Physico-Chemical Characterization of Industrial Liquid Discharges of Soap Factories in Abidjan, Côte D'Ivoire. J. Geosci and Env Protect, 5, 198-210 http://www.scirp.org/journal/gep.

[14] Rodier J. (2009). L'Analyse de l'Eau: Eaux Naturelles, Eaux Résiduaires et Eaux de Mer (9 $9^{\text {ème }}$ édn). DUNOD: Paris; 1384 Pp. 
[15] ISO 7875-1 (1996). Water Quality. Determination of Surfactants: Part 1, Determination of Anionic Surfactants by Measurement of the Methylene Blue Index (MBAS).

[16] GAILLARD M. L. (2015). Indice des agents de surface anioniques, comparaison des méthodes globales (spectrophotométrie avec ou sans reflux). Association Générale des Laboratoires d'Analyses de l'Environnement (AGLAE). Note Technique $N^{\circ} 3$. Pp 33.

[17] Ballet, T. G. N., Effebi, K. R., Ako, O. Y. A., Kpidi, Y. H. and Yapo, O. B. (2018). Anionic Surfactants Levels in M'Koa Lake Water (Jacqueville, Cote d'Ivoire). Journal of Water Resource and Protection, 10, 1210-1221. https://doi.org/10.4236/jwarp.2018.1012072.

[18] INERIS-Republique Française. Arrêté type- Rubrique ${ }^{\circ} 170$. Détergents (Fabrication des produits autres que les savons). Pp 3.

[19] Bergé A, Wiest L, Giroud B, Baudot R, Vulliet E (2017): Occurrence of multi-class surfactants in urban wastewater: contribution of a healthcare facility to the pollution transported into the sewerage system, Environmental Science and Pollution Research, online, DOI: 10.1007/s11356-017-0470-8.

[20] HAMPEL M., MORENO-GARRIDO L., SOBRINO C., LUBIAN L. M., BLASCO, J. (2001). Acute toxicity of LAS homologues in marine microalgae: Esterase activity and inhibition growth as endpoints of toxicity. Eeotox. Env. Sale 48: 287-292.
[21] SAEZ M., LEON V. M., GEMEZ-PARRA A., GONZALEZ-MAZO E. Extraction and isolation of linear alkylbenzene sulfonate and their intermediate metabolites from various marine organisms. J. Chromatogr. A. 889: 99-104.

[22] Ulva lactuca. Kanaji Masakorala \& Andrew Turner \& Murray T. Brown. Toxicity of Synthetic Surfactants to the Marine Macroalga. Water Air Soil Pollut (2011) 218: 283-291 DOI 10.1007/s11270-010-0641-4.

[23] J. Hammer, A. M. Tukker, J. F. Postma J. J. H. Haftka J. L. M. Hermens P. de Voogt M. H. S. Kraak (2018). Solubility Constraints on Aquatic Ecotoxicity Testing of Anionic Surfactants. Bulletin of Environmental Contamination and $\begin{array}{llll}\text { Toxicology } & \text { (2018) } & \text { 101: } & 99-104\end{array}$ https://doi.org/10.1007/s00128-018-2361-1.

[24] Jean Missa Ehouman (2018). Caractérisation physico-chimique des rejets liquides industriels de savonneries et prédiction de la stabilité chimique de quelques surfactants anioniques des produits détergents. Thèse de doctorat, Université Nangui Abrogoua, Abidjan, Côte d'Ivoire. Pp 202.

[25] SANCHEZ L. J., GARCIA M. T., TOMAS R., FERRER J., BENGOECHEA, C. (1994). Linear alkylbenzene sulfonate removal. Tens. Surfaet. Oet. 31: 253-256.

[26] FAUSER P., VIKELSOE J., SERENSEN P. B., CARLSEN, L. (2003). Phtalates, nonylphenols and LAS in an alternately operated wastewater treatment plant-tate modelling based on measured concentrations in wastewater and sludge. Wat. Res 37: 1288-1295. 